\title{
MODULADORES DA BIOSSÍNTESE E DO MECANISMO DE AÇÃO DO ETILENO SOBRE O CRESCIMENTO IN VITRO DO PORTA-ENXERTO DE MACIEIRA MARUBAKAIDO
}

\author{
MODULATORS OF THE BIOSYNTHESIS AND OF THE MECHANISM OF \\ ACTION OF ETHYLENO ON THE GROWTH IN VITRO OF APPLE \\ MARUBAKAIDO'S STOCK
}

\author{
Sandra Aparecida MEDEIRO \\ Orientador(a): Prof. Dr. Adaucto Bellarmino PEREIRA NETTO \\ (Departamento de Botânica)
}

\begin{abstract}
RESUMO
A utilização de frascos de cultura com tampas que dificultam trocas gasosas entre o ambiente interno e externo dos frascos resulta em aumento considerável na concentração interna de etileno nos frascos de cultura, o que freqüentemente ocasiona redução na taxa de multiplicação de material vegetal in vitro. A redução da concentração do etileno na atmosfera interna dos frascos de cultura, por meio de inibição da biossíntese, ou da inibição do seu mecanismo de ação, tem promovido o aumento na taxa de multiplicação, o que reduz o tempo e o custo de produção de mudas micropropagadas. Neste trabalho, objetivou-se aumentar a taxa de multiplicação in vitro para o porta-enxerto de macieira Marubakaido pelo uso de compostos conhecidos por inibir a biossíntese ou o mecanismo de ação do etileno. Segmentos nodais de Malus prunifolia cv Marubakaido cultivado in vitro foram inoculados em meio de cultura MS (MURASHIGE e SKOOG,1962) suplementado com 2,22 $\mu \mathrm{M}$ de Benzilaminopurina, e mantidos em sala de prescimento a $27 \pm 2{ }^{\circ} \mathrm{C}$, fotoperíodo de 16 horas, Densidade de Fluxo de Radiação Fotossinteticamente Ativa (RFA) de $40 \mathrm{mmol} . \mathrm{m}^{-2} \cdot \mathrm{s}^{-1} \mathrm{e}$ umidade relativa do ar de $75 \pm 5 \%$. AVG (L-a-(2-aminoetoxivinil-glicina), AIB (ácido a-aminoisobutírico), $\mathrm{CoCl}_{2}$ (dicloreto de cobalto), e os brassinoesteróides 28-HCTS (homoetilcastasterona) e 5F-HCTS (28-homoetil5-flúor-castasterona), compostos moduladores da biossíntese do etileno, além de STS (tiossulfato de prata) e 1-MCP (1-metilciclopropano), conhecidos inibidores do mecanismo de ação do etileno foram empregados neste estudo, pela adição à atmosfera interna do frasco de cultivo, no caso do 1-MCP, e de aplicação foliar, no caso dos brassinoesteróides, ou pela adição ao meio de cultura, no caso dos demais compostos químicos mencionados. As variáveis avaliadas foram: comprimento das partes aéreas e sua hierarquia; número de partes aéreas medindo $1,5 \mathrm{~cm}$ de comprimento ou mais e partes aéreas medindo menos de $1,5 \mathrm{~cm}$, com identificação de sua hierarquia; e taxa de multiplicação dos explantes (número de segmentos nodais e ápices caulinares, aptos a multiplicação in vitro). Os resultados obtidos mostraram que, dentre as variáveis avaliadas, o número de ramos principais $<1,5 \mathrm{~cm}$ apresentou aumento da ordem de $74 \%$ quando o AVG estava presente na concentração de $5 \mu \mathrm{M}$ no meio de cultura. Para o $\mathrm{CoCl}_{2}$, houve redução significativa em todas as variáveis avaliadas. Nenhuma alteração significativa foi encontrada para comprimento de ramos, número de ramos laterais ou taxa de multiplicação quando o AIB estava presente no meio de cultura. Para os tratamentos com 1-MCP e STS, os resultados apontaram para redução na taxa de multiplicação do material vegetal. Dentre os brassinoesteróides testados, somente o 5F-HCTS apresentou respostas 1 significativas. Aumento da ordem de $83 \%$ na taxa de multiplicação do ramo principal mostrou-se relacionado à dose de $1 \mu \mathrm{g}$.parte aérea do $5 \mathrm{~F}$-HCTS, tendo também sido observada elevação da ordem de $52 \%$ no número de ramos laterais ${ }^{3} 1,5 \mathrm{~cm}$ nesta dose de $5 \mathrm{~F}$-HCTS. Concluindo, o brassinoesteróide $5 \mathrm{~F}$-HCTS apresenta potencial para ser utilizado com o objetivo de aprimorar a técnica de propagação in vitro para o porta-enxerto de macieira Marubakaido.

Palavras-chave: etileno, taxa de multiplicação, Malus prunifolia, brassinoesteróide.
\end{abstract}

\section{ABSTRACT}

Lids used in culture vessels usually constrain gas exchange between the inner and outer vessel's atmosphere. This constrain typically leads to a considerable raise in the internal ethylene concentration which often cause reduction on the multiplication rate for in vitro-grown tissues. Reduction on the internal ethylene concentration through the inhibition of the growth regulator biosynthesis or signal transduction pathway has increased multiplication rate (MR) in various systems. This increase on MR reduce micropropagation cost and time. This study aimed to increase in vitro MR for the Marubakaido apple rootstock through the use of compounds known to inhibit ethylene biosynthesis or signal transduction pathway. Nodal segments of a clone of Malus prunifolia cv Marubakaido were grown in MS (MURASHIGE e SKOOG,1962) culture medium supplemented with $2,22 \mu \mathrm{M}$ benzylaminopurine. Explants were kept in growth room at $27 \pm 2{ }^{\circ} \mathrm{C}, 16$-hours photoperiod,

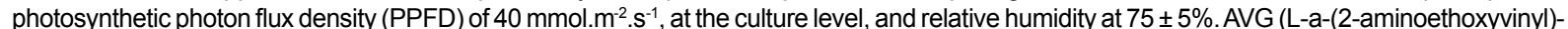
glycine), AIB (a-aminoisobutyric acid), $\mathrm{CoCl}_{2}$ (cobalt dichlorate), and brassinosteroids 28-HCTS (homoethylcastasterone) and 5F-HCTS (28homoethil-5-fluor-castasterone), inhibitors of ethylene biosynthesis, and STS (silver thiosulphate) and 1-MCP (1-methylcyclopropane), well known inhibitors of the ethylene sinal transduction pathway were used in this study through the addition to the culture vessel's internal atmosphere, in the case of 1-MCP, through leaf application, in the case of brassinosteroids, or through the addition to the culture media, in the case of the other mentioned chemicals. Evaluation consisted of measurements of shoot length and their hierarchy distribution, number of shoots measuring $1,5 \mathrm{~cm}$ or more in length, number of shoots measuring less than $1,5 \mathrm{~cm}$ in length, also with their hierarchy distribution, and multiplication rate (number of shoot apices and nodal segments useful for micropropagation purposes). A $74 \%$ increase on the number of main branches $<1,5 \mathrm{~cm}$ was related to the presence of AVG at $5 \mu \mathrm{M}$ in the culture medium. No significant change for any of the measured parameters was found for shoots grown in $\mathrm{CoCl}_{2}$ or AIB-containing media. Reduction on MR was found for all of the 1-MCP and STS treatments. Among the brassinosteroids, only 5F-HCTS induced significant changes on shoot growth dynamics. An $83 \%$ increase on MR was related to the dose of $1 \mu \mathrm{g}$.shoot. This increase on MR was related to a raise of $52 \%$ on the number of lateral branches ${ }^{3} 1,5 \mathrm{~cm}$. Concluding, the $5 \mathrm{~F}-\mathrm{HCTS}$ shows potential to be used on the improvement of the in vitro propagation technique for the Marubakaido apple rootstock. Key-words: ethylene, multiplication rate, Malus prunifolia, brassinosteroid. 